\title{
Cell Line Generation: Relying on tricks or tools of the trade?
}

\author{
Jeff JC Hou*, Eric Zhu, Michael Song, Kar M Leung, Martina Jones, Trent P Munro, Peter P Gray \\ From 24th European Society for Animal Cell Technology (ESACT) Meeting: C2P2: Cells, Culture, Patients, Products \\ Barcelona, Spain. 31 May - 3 June 2015
}

\begin{abstract}
Background
Cell line generation (CLG) in the scope of bioproduction can be defined as a method to isolate a single cell expressing a recombinant protein of interest. The standard method of CLG often involves the introduction of the transgene into a cell in an attempt to use the cellular machinery for transcription, translation and secretion. The use of random genomic integration via auxotrophic selection markers creates different layers of complexity, which leads to significant variations in growth, productivity and stability among the subsequent population [1]. The use of epigenetic modulators with genetically improved cell lines have improved the "quality" of the resistant pools [2], while high throughput technologies have simplified the clonal isolation process [3]. However this "blackbox" approach still requires the need to screen hundreds or thousands of individual cells to find a line with the right quality attributes for manufacturing [4]. The challenge for CLG is to significantly reduce the timeline of this process while ensuring robustness and quality of the subsequent clones [5].
\end{abstract}

\section{Materials and methods}

The changing landscape of CLG has resulted in the inclusion of robotics and high throughput technologies such as flow cytometry into development pipelines. The standard CLG method may include (but not limited to) transfection, selection and stable pool generation followed by a number of rounds of clonal enrichment using the new technologies to isolate cells with the necessary quality attributes for product manufacturing. However we present a single step method to isolate $\mathrm{CHO}$ cells for the expression of monoclonal antibodies $(\mathrm{mAb})$. The method employed here uses semi solid

Australian Institute for Bioengineering and Nanotechnology (AIBN), University of Queensland Corner of Cooper and College Roads, Brisbane, QLD 4067, Australia

C 2015 Hou et al. This is an Open Access article distributed under the terms of the Creative Commons Attribution License (http:// creativecommons.org/licenses/by/4.0), which permits unrestricted use, distribution, and reproduction in any medium, provided the original work is properly cited. The Creative Commons Public Domain Dedication waiver (http://creativecommons.org/publicdomain/ zero/1.0/) applies to the data made available in this article, unless otherwise stated. cloning as well as the ClonePix FL (Molecular Devices) to isolate $\mathrm{mAb}$ producing $\mathrm{CHO}$ cells. The method examines directly seeding transfected cells into a semisolid matrix for selection, propagation and subsequent in a single step, this direct approach allows for a more efficient process in identifying a "serendipity event", i.e. a single cell that has been transfected with the vector containing the gene of interest, undergone random integration/s at a non-essential locus and now has the ability to express the recombinant protein of interest. Transfected cells were seeded into semi-solid matrix at different seeding densities and then the positive colonies were isolated using the ClonePix FL. The clones were assessed for growth and productivity between the single step and the standard methods.

\section{Results}

To assess the single step method, we examined the growth, productivity and interclonal diversity from the isolated clones. For colony formation in the semi solid matrix, initial seeding density was increased from 5001000 cells $/ \mathrm{mL}$ as recommended [2] to $40,000-80,000$ cells/mL. Using the Clone Select Imager (Molecular Devices), visible colonies were seen in the semi solid matrix. An initial assessment via the FITC intensity of the in situ fluorescence complex between the Clone Detect (Molecular Devices) and the protein of interest showed a higher signal from the single step method when compared to the standard method. Both methods showed that isolated clones were able to reach 10 million cells $/ \mathrm{mL}$ with specific productivity ranging from 10 to $50 \mathrm{pg} / \mathrm{cell} /$ day. It was clear the standard method provided $\mathrm{CHO}$ clones with better growth characteristics while the single step method allowed for the isolation of clones with significantly greater specific productivity. isolation. By combining the selection with the isolation 


\section{Conclusions}

The single step method presents a simple change in methodology for increasing the probability of isolating a $\mathrm{mAb}$ expressing $\mathrm{CHO}$ line without changing the fundamental process. In fact, by directly seeding the transfected cells into the semi solid matrix, the method presents a more robust process eliminating the need for bulk selection and a resistant pool, while also reducing current timelines for CLG. With the rapid changes in the biopharmaceutical industry, especially in biosimilar developments [6], being able to establish a simple and robust process for CLG can have a significant impact on both novel and biosimilar pipelines.

\section{Acknowledgements}

The authors acknowledge the Australian Commonwealth Government's NCRIS Program and co-support from the Queensland State Government.

Published: 14 December 2015

\section{References}

1. Porter AJ, Racher AJ, Preziosi R, Dickson AJ: Strategies for selecting recombinant $\mathrm{CHO}$ cell lines for $\mathrm{CGMP}$ manufacturing: improving the efficiency of cell line generation. Biotechnol Prog 2010, 26(5):1455-1464.

2. Hou JJ, Hughes BS, Smede M, Leung KM, Levine K, Rigby S, Gray PP, Munro TP: High-throughput ClonePix FL analysis of mAb-expressing clones using the UCOE expression system. N Biotechnol 2014, 31(3):214-220.

3. Nakamura T, Omasa T: Optimization of cell line development in the GS$\mathrm{CHO}$ expression system using a high-throughput, single cell-based clone selection system. Journal of bioscience and bioengineering 2015.

4. Pybus LP, Dadehbeigi N, Saunders FL, Porter AJ: Delivering 'fit for purpose' biomanufacturing CHO cell lines. FUJIFILM Diosynth Biotechnologies 2014, November, 2014: 1-7.

5. Estes S, Melville M: Mammalian cell line developments in speed and efficiency. Advances in biochemical engineering/biotechnology 2014, 139:11-33.

6. Hou JJC, Codamo J, Pilbrough W, Hughes B, Gray PP, Munro TP: New frontiers in cell line development: Challenges for biosimilars. Journal of Chemical Technology and Biotechnology 2011.

doi:10.1186/1753-6561-9-S9-P16

Cite this article as: Hou et al:: Cell Line Generation: Relying on tricks or tools of the trade? BMC Proceedings 2015 9(Suppl 9):P16.

\section{Submit your next manuscript to BioMed Central} and take full advantage of:

- Convenient online submission

- Thorough peer review

- No space constraints or color figure charges

- Immediate publication on acceptance

- Inclusion in PubMed, CAS, Scopus and Google Scholar

- Research which is freely available for redistribution

Submit your manuscript at www.biomedcentral.com/submit
C Biomed Central 